Наносистели, нанолатеріали, нанотехнології Nanosistemi, Nanomateriali, Nanotehnologii 2019, т. 17, № 1, сc. 133-144 (c) 2019 ІМФ (Інститут металофізики ім. Г. В. Курдюмова НАН України) Надруковано в Україні. Фотокопіювання дозволено тільки відповідно до ліцензії

PACS numbers: 02.70.Ns, 61.46.Bc, 61.46.Df, 68.35.Md, 68.43.Bc, 68.43.Fg, 82.75.-z

\title{
Binding Preference of $\alpha$-Cyclodextrin onto Gold Nanoparticles
}

\author{
M. V. Slavgorodska and A. V. Kyrychenko \\ V. N. Karazin Kharkiv National University, \\ 4 Svobody Square, \\ 61022 Kharkiv, Ukraine
}

The binding preference of $\alpha$-cyclodextrin $(\alpha-C D)$ onto the surface of a gold nanoparticle is studied by means of molecular dynamics (MD) simulations. As found, the $\alpha$-CD molecules bind onto the nanoparticle surface at the nanosecond time scale. Adsorption onto the gold nanoparticle surface occurs through multiple non-covalent interactions, among which non-covalent bonding of the aliphatic carbon atoms of $\alpha$-CD play a key role. The analysis shows that a $\alpha$-CD molecule prefers to bind onto the gold surface by its cone side. In addition, the MD simulations reveal that, upon the increase in concentration, the self-aggregation and steric repulsion among adsorbed $\alpha$-CD molecules affect its binding preference onto the surface of a gold nanoparticle.

\begin{abstract}
Методою молекулярно-динамічного моделювання досліджено адсорбцію $\alpha$-циклодекстрину ( $\alpha$-ЦД) на поверхню наночастинки золота. Встановлено, що молекули $\alpha$-ЦД адсорбуються на поверхню наночастинки у наносекундній шкалі часу. Адсорбція на поверхню наночастинки золота відбувається за рахунок численних нековалентних взаємодій, серед яких нековалентні зв'язування аліфатичних атомів Карбону $\alpha$-ЦД мають вирішальну роль. Аналіза показує, що молекули $\alpha$-ЦД переважно адсорбуються на поверхню золота за рахунок зовнішньої сторони кільця. МДмоделювання виявило, що при збільшенні концентрації $\alpha$-ЦД їх агрегація та стеричні відштовхування між адсорбованими молекулами впливають на переважну конфігурацію зв’язування з поверхнею золота.
\end{abstract}

Методом молекулярно-динамического моделирования изучена адсорбция $\alpha$-циклодекстрина ( $\alpha$-ЦД) на поверхность наночастицы золота. Установлено, что молекулы $\alpha$-ЦД адсорбируются на поверхность наночастицы в наносекундной временной шкале. Адсорбция на поверхность наночастицы золота происходит за счёт различных нековалентных взаимодействий, среди которых нековалентные связывания алифатических атомов углерода $\alpha$-ЦД играют определяющую роль. Анализ показывает, что молекулы $\alpha$-ЦД предпочтительно адсорбируются на поверхность золота за счёт внешней стороны кольца. МД-моделирование показало, что при увеличе- 
нии концентрации $\alpha-Ц Д$ их агрегация и стерические отталкивания между адсорбированными молекулами влияют на предпочтительную конфигурацию связывания с поверхностью золота.

Key words: gold nanoparticle, cyclodextrin, $\alpha$-CD, molecular dynamics simulation, adsorption.

Ключові слова: наночастинка золота, циклодекстрин, $\alpha$-ЦД, молекулярно-динамічне моделювання, адсорбція.

Ключевые слова: наночастица золота, циклодекстрин, $\alpha$-ЦД, молекулярно-динамическое моделирование, адсорбция.

(Received 29 January, 2019)

\section{INTRODUCTION}

The emerging and fascinating world of gold nanoparticles (AuNPs) is continuing to receive a great deal of both academic and industrial interest due to their unique optical, electronic, magnetic, and catalytic properties [1]. Physicochemical characteristics of AuNPs make them very appealing for a variety of applications in multidisciplinary fields, spanning from molecular electronics to nanomedicine [1-3]. AuNPs can be prepared by simple chemical reactions in solutions. However, the commonly used synthetic methods generally result in rather large $(20-100 \mathrm{~nm})$ and highly polydisperse $(5-50 \mathrm{~nm})$ nanoparticles because of the aggregation of freshly formed gold nanoclusters [2]. Various capping agents, which interact with the nanoparticles during the condensation and, thus, prevent them from agglomeration, have been utilized to effectively stabilize and uniform the size of AuNPs [4].

Non-toxic and biocompatible cyclodextrins (CDs) have often been used to prepare gold nanoparticles in the presence of different reducing agents such as dimethyl formamide, ethanol, methanol, ethylene glycol, and sodium citrate [5-8]. $\alpha$-Cyclodextrin $(\alpha-C D)$ is a cyclic hexasaccharide, derived from glucose and composed of six Dglucose repeating units (Fig. 1). Despite of a large number of investigations focused on utilizing CDs, the structural details and the mechanism for the stabilization of AuNPs by CDs have not been well understood. Therefore, further studies are still needed. A more detailed understanding of the binding configuration preferences of adsorbed CDs molecules can aid in addressing some questions related to a number of interfacial phenomena observed for cyclodextrinstabilized AuNPs.

A deeper knowledge and insight into the structural characterization of surface-adsorbed CDs molecules are essential for the rational 
synthesis of AuNPs. However, due to the complexity of inorganic/organic interfaces, it remains challenging to achieve this goal via experimental approaches alone. Therefore, it has been shown that theoretical and atomic-scale computational chemistry methods have become the powerful supplementary tools for studying of the stabilizing mechanism of metal nanoparticles in aqueous solution [9-16].

The purpose of the present work is to study interactions, adsorption, and binding preference of $\alpha-C D$ on a gold nanoparticle by using classical MD simulations. We studied how multiple molecules of $\alpha-C D$, which were randomly distributed around the nanoparticle in bulk aqueous solution at the beginning of sampling, bind and adsorb onto the crystalline gold surface. One of the goals of the present work was also to examine the preferred configuration of $\alpha$-CD molecules adsorbed onto the non-uniform gold surface.

\section{MOLECULAR DYNAMICS SIMULATION SETUP}

\subsection{Force Field Parameters for AuNP}

A gold nanoparticle was modelled at the atomic level as a truncated polyhedron, which is known to be one of the thermodynamic equilibrium shapes of colloidal gold in solution [2, 17]. The gold core was approximated by a quasi-spherical nanocrystal composed of the fixed number of 1007 gold atoms, which positions are generated from a face-centred cubic (f.c.c.) unit cell with a cell parameter of $0.408 \mathrm{~nm}$. The average diameter of such a nanoparticle core equals to $2.9 \mathrm{~nm}$, as shown in Fig. 1 .

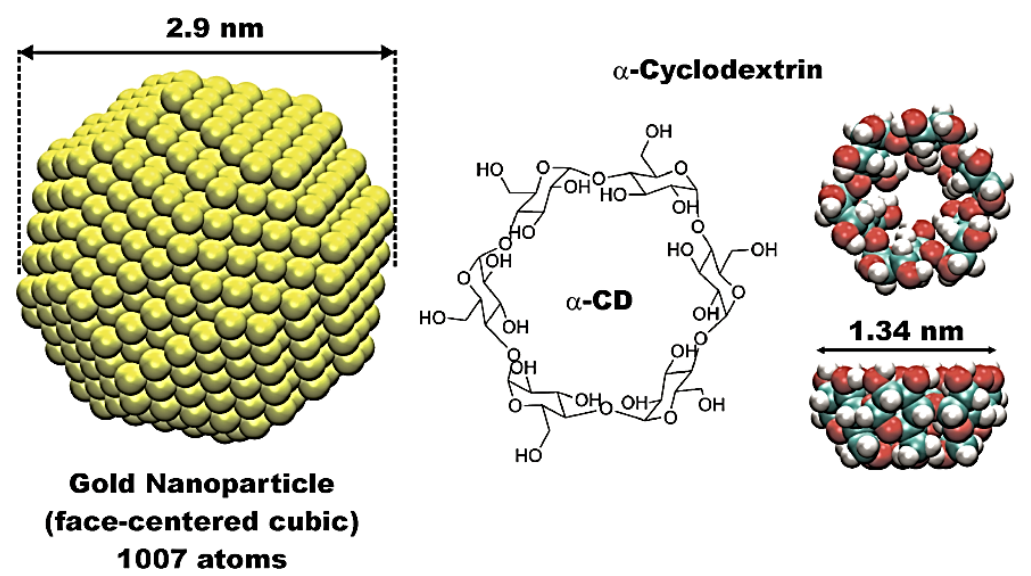

Fig. 1. A quasi-spherical gold nanoparticle with the average diameter of 2.9 nm. Molecular structure of $\alpha$-cyclodextrin $(\alpha-C D)$ and its top and side views. 
The repulsion and dispersion terms of non-bonding interactions between $\mathrm{Au}$ atoms were computed by using the Lennard-Jones (LJ) 12-6 pairwise potential energy function (Eq. (1)). Suitable nonbonding interaction parameters $\sigma=0.2629 \mathrm{~nm}$ and $\varepsilon=22.13 \mathrm{~kJ} / \mathrm{mol}$ were adopted from the recent work of Heinz and co-workers [18], in which the 12-6 LJ pair potential was fitted to reproduce densities, surface tensions, and interface properties of face-centred cubic crystal of a gold:

$$
\begin{aligned}
& V_{L J}\left(r_{i j}\right)=4 \varepsilon_{i j}\left(\left(\frac{\sigma_{i j}}{r_{i j}}\right)^{12}-\left(\frac{\sigma_{i j}}{r_{i j}}\right)^{6}\right) \text { for } r<r_{\text {cutoff }} ; \\
& V_{L J}\left(r_{i j}\right)=0 \text { for } r>r_{\text {cutoff }} .
\end{aligned}
$$

For mixed non-bonding interactions between $\mathrm{Au}, \alpha$-CD molecules and water atoms, the Lorentz-Berthelot combination rules (Eq. (2), (3)) were used:

$$
\begin{gathered}
\sigma_{i j}=\frac{1}{2}\left(\sigma_{i i}+\sigma_{j j}\right), \\
\varepsilon_{i j}=\left(\varepsilon_{i i} \varepsilon_{j j}\right)^{1 / 2} .
\end{gathered}
$$

\subsection{Force Field Parameters for $\alpha$-Cyclodextrin}

$\alpha$-Cyclodextrin $(\alpha-C D)$ is cyclic $\alpha-(1 \rightarrow 4)$-linked carbohydrate oligomers constructed from D-glucose units (Figure 1). $\alpha$-CD comprises six units of a glucopyranose monomer [19]. The three-dimensional molecular structure of $\alpha$-CD resembles a truncated cone with the primary and secondary hydroxyl groups on the broader and narrower cone rims, respectively (Figure 1). The interior of $\alpha$-CD is less hydrophilic and allows hydrophobic molecules to be included within the cavity. It is expected that various kinds of hydrophobic and van der Waals interactions govern the adsorption of $\alpha$-CD molecules onto the surface of metal nanoparticles.

In recent years, the structure, conformational dynamics, and solvation behaviour of native and substituted CDs have been subject of numerous theoretical studies by means of MD simulations [2043], $a b$ initio quantum chemistry [44-48] and hybrid QM/MM methods [49]. From computational point of views, physicochemical properties of $\alpha$-, $\beta$ - and $\gamma$-CDs were considered by using many popular MD force fields, such as all-atom CHARMM [35-42], AMBER [20, 33, 34], and GLYCAM [20, 22-24], respectively. Several variants of the united-atom GROMOS force fields for MD simulations of 
carbohydrates and polysaccharides have also been developed [21, 25-32].

In our study, the $\alpha$-CD molecule is described by all-atom CHARMM36 force field parameters [50]. Employing of the CHARMM FF, which operates with the same functional form and the combination rules for non-bonding interactions between $\mathrm{Au}-\mathrm{Au}$ and $\mathrm{Au}-\alpha-\mathrm{CD}$, enables MD simulations of a broad range of inorganic-organic and inorganic-biomolecular interfaces. Recently, such approach has been validated in the CHARMM-INTERFACE force field $[51,52]$.

\subsection{Molecular Models of $\alpha-\mathrm{CD}-\mathrm{AuNP}_{1007}$}

The AuNP $\mathrm{P}_{1007}$ was placed in the centre of the cubic box with the size of $7.43 \mathrm{~nm}$. Next, two systems were prepared, in which either 10 or $60 \alpha$-CD molecules were placed randomly in the same box as shown in Fig. 2, $a, c$, respectively. The rest of the box was filled with 10700-11500 explicit water molecules at a density of $1.0 \mathrm{~g} / \mathrm{cm}^{3}$. The water molecules are described by the simple point charge (SPC) model [53]. The size of the water box was chosen to ensure that the systems have at least $10 \AA$ solvation shell in all directions. To study water accessibility toward a gold nanoparticle core, a control MD simulation of a bare $\mathrm{AuNP}_{1007}$ in water was also carried out. Figure $2 a$ and $2 c$ show the initial configurations of $\alpha-\mathrm{CD}_{10}-\mathrm{AuNP}_{1007}$ and $\alpha-$ $\mathrm{CD}_{60}-\mathrm{AuNP}_{1007}$ in a MD box.

\subsection{Simulation Setup}

The MD simulations were carried out for a NPT ensemble. The reference temperature of $298.15 \mathrm{~K}$ was kept constant using the $\mathrm{V}$ rescale weak coupling scheme [54] with the coupling constant $\tau_{T}=0.1 \mathrm{ps}$. The constant pressure of $1 \mathrm{~atm}$ was maintained by using Parrinello-Rahman barostat with the coupling constant $\tau_{P}=1$ ps. The initial atomic velocities were generated with a Maxwellian distribution at the given absolute temperature. Periodic boundary conditions were applied to all three directions of the simulated box. Electrostatic interactions were simulated with the particle mesh Ewald (PME) approach [55] using the long-range cut-off of $1.0 \mathrm{~nm}$. The cut-off distance of Lennard-Jones interactions was also equal to $1.0 \mathrm{~nm}$. The MD simulation time step was $2 \mathrm{fs}$ with the neighbour list updates every $10 \mathrm{fs}$. All bond lengths were kept constant using the LINCS routine [56, 57]. The MD simulations were carried out using the GROMACS set of programs, version 4.6 [58]. Molecular graphics and visualization were performed using VMD 1.9.2 [59]. 

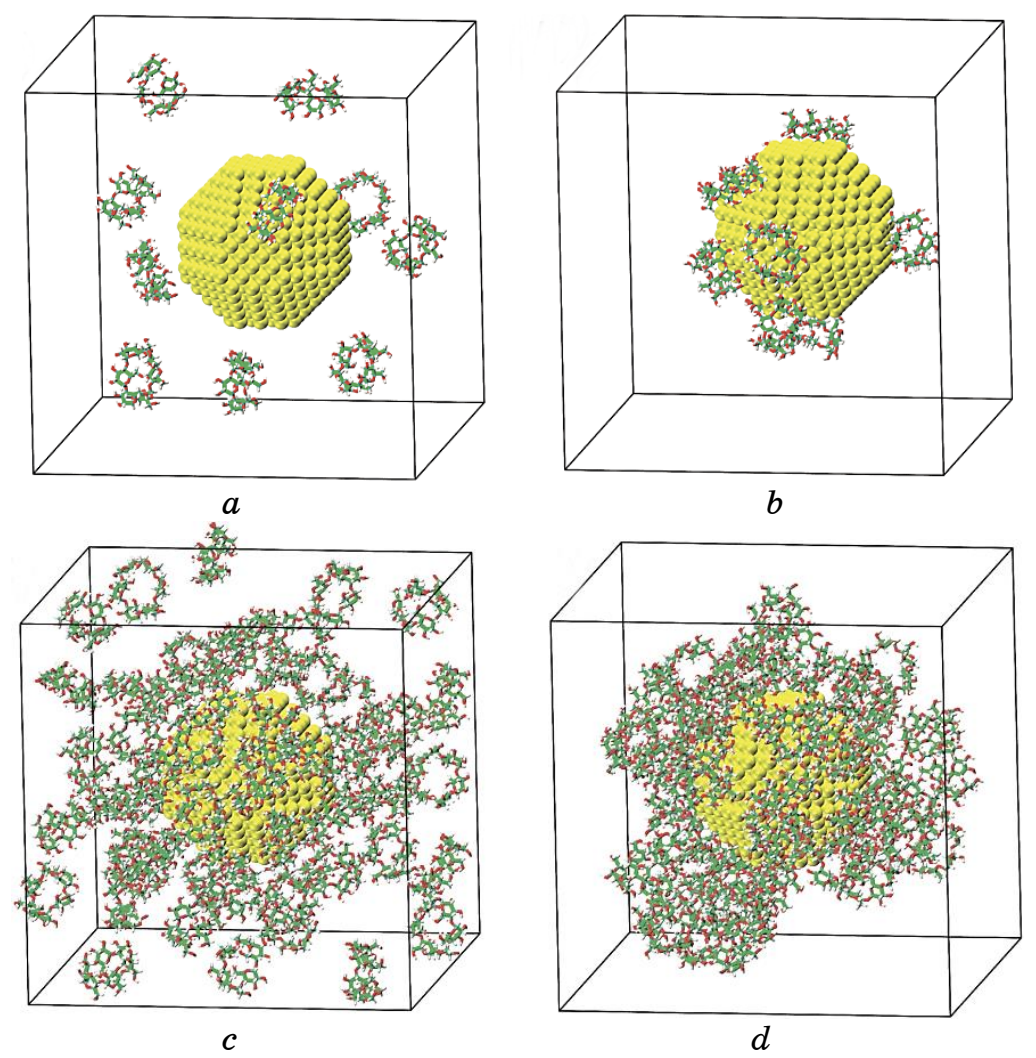

Fig. 2. MD simulations of adsorption dynamics of $\alpha-C D$ molecules onto the AuNP core. The initial ( $a$ and $c$ ) and final ( $b$ and $d$ ) configurations of the systems composed of $10(a, b)$ and $60(c, d) \alpha$-CD molecules, respectively. The gold atoms are shown by means of a van der Waals model. Water molecules are not shown for clarity.

\section{RESULTS AND DISCUSSION}

Our approach for studying the binding preference of $\alpha$-CD on a curved non-uniform surface of $\mathrm{AuNP}_{1007}$ is based on MD simulations of equilibrium adsorption of a discrete number of $\alpha$-CD molecules from bulk water to the water/gold interface. The two systems composed of either 10 or $60 \alpha-C D$ molecules were considered. These equilibrium MD samplings were followed by identification of interatomic interactions between adsorbed $\alpha$-CDs that were found to be in contact with the metal surface. In addition, intermolecular interactions between adsorbed CDs and water molecules were also considered. 


\subsection{Adsorption Dynamics of $\alpha$-CDs on $\mathrm{AuNP}_{1007}$}

The initial configuration of the systems corresponds to the $\mathrm{AuNP}_{1007}$ placed in the centre of the box. On the next step, either 10 or 60 molecules of $\alpha$-CD were randomly distributed around the AuNP core (Fig. 2, $a, c$ ). During the MD simulations, the majority of $\alpha$-CD molecules become adsorbed onto the $\mathrm{AuNP}_{1007}$ in the nanosecond time scale, which suggests the high binding affinity of $\alpha$-CD to gold. Each $\alpha$-CD molecule was considered to be adsorbed onto the $\mathrm{AuNP}_{1007}$, if its heavy atoms lie within the cut-off distance of $3.5 \AA$ from the outermost gold atoms. Figures $2, b, d$ show the final configurations of $\alpha-\mathrm{CD}_{10}-\mathrm{AuNP} \mathrm{P}_{1007}$ and $\alpha-\mathrm{CD}_{60}-\mathrm{AuNP} \mathrm{P}_{1007}$ after $120 \mathrm{~ns}$.

Figure 3, $a$ shows time traces of the number of interatomic contacts between the outermost gold atoms of $\mathrm{AuNP}_{1007}$ and the atoms of $60 \alpha$ CD molecules, referred to as AuNP-to- $\alpha$-CD. As can be seen, the number of neighbouring contacts AuNP-to- $\alpha$-CD is gradually increased from $\cong 300$ up to 1100 during the first $40 \mathrm{ns,}$ pointing out to rapid adsorption of $\alpha$-CD molecules onto the $\mathrm{AuNP}_{1007}$ core. This increase was accompanied by a simultaneous decrease in the number of neighbouring contacts between AuNP and the water molecules (AuNP-to-water), occurring on the same time scale of $40 \mathrm{~ns}$ (Fig. 3, $b$ ). After $\cong 50 \mathrm{~ns}$, the number contacts of AuNP-to- $\alpha-C D$ and AuNP-to-water demonstrate some convergence, seen as plateauing and random fluctuations around some average values of $1083 \pm 25$ and $1015 \pm 30$, respectively. This behaviour suggests that the system reaches an equilibrium distribution of $\alpha$-CD molecules at the water/gold interface.

It can be noted in Fig. 2, $d$ that almost all $\alpha$-CD molecules become adsorbed onto the AuNP $\mathrm{A}_{1007}$. Accordingly, the number of water
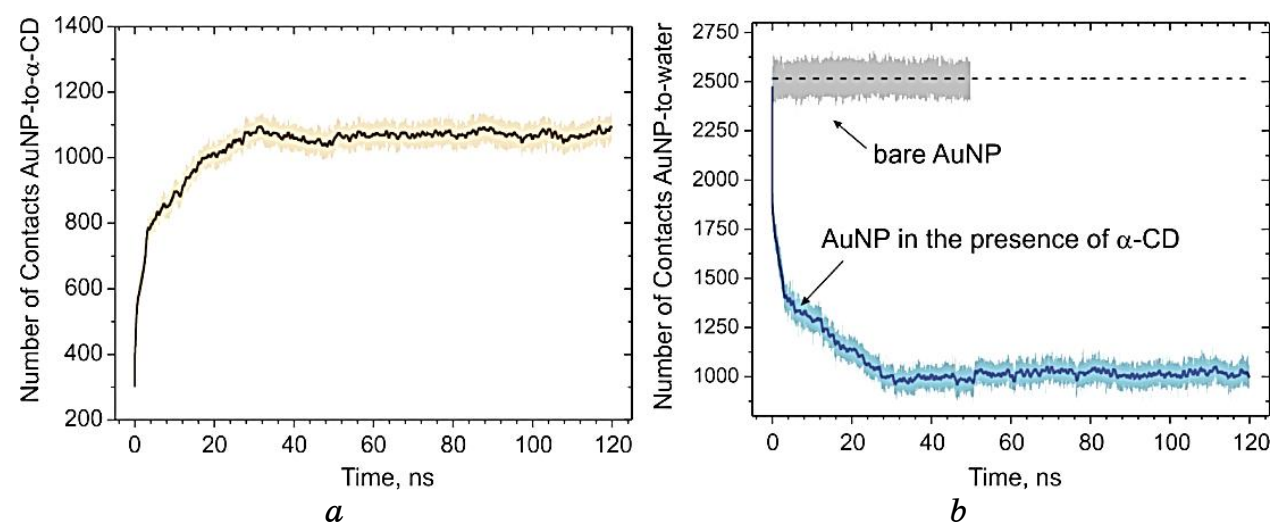

Fig. 3. Time evolution of the number of contacts between the AuNP atoms and $(a)$ the $60 \alpha$-CD molecules (AuNP-to- $\alpha-C D)$ and $(b)$ the water molecules (AuNP-to-water). 
molecules directly interacting with the $\mathrm{AuNP}_{1007}$ decreases with respect to an increase in the number of $\alpha$-CD molecules in the solution. The existence of a large fraction of residual water molecules directly interacting with the $\mathrm{AuNP}_{1007}$ is due to the inability of adsorbed $\alpha-C D$ molecules to cover completely the $\mathrm{AuNP}_{1007}$ surface due to steric crowding and size effects. For example, when $\alpha$-CD molecules have been adsorbed on the surface of the $\mathrm{AuNP}_{1007}$, there still may be a part of the surface, which is too small to accommodate another $\alpha$-CD molecule, so that such voids between the adsorbed $\alpha$ CD molecules may accommodate some water molecules. The analysis of the adsorbed layer of $\alpha-C D$ molecules indicates that further adsorption of guest molecules is still be possible if $\alpha$-CD concentration is increased in the system. The structural analysis demonstrated that $\alpha$-CD molecules adsorb onto the AuNP surface through multiple non-covalent interactions, among which non-covalent bonding of the aliphatic carbon moieties a key role.

\subsection{Binding Preference of $\alpha-\mathrm{CdS}$ on AuNP}

It has been suggested that the stabilization of the metal nanoparticles was achieved by hydrophobic interactions [60]. In addition, hydrogen-bonding interactions between the hydroxyl groups of neighbouring $\alpha$-CDs, could lead to their self-assembly.

$\alpha$-CD has a toroidal form and can be sketched as a truncated cone (Fig. 1). The narrower rim of the truncated cone contains six secondary hydroxyl groups, the wider rim contains 12 primary hydroxyl groups. Both rims are hydrophilic due to H-bonding with water molecules, while the cavity is more hydrophobic. Possible binding modes of a $\alpha$-CD molecule onto the flat gold surface are schematically summarized in Fig. 4.

The analysis the adsorbed molecules on $\mathrm{AuNP}_{1007}$ revealed that, in the system composed of $10 \alpha$-CD molecules, about $20 \%$ and $80 \%$ of the population adopted the configuration of the primary rim (Fig. 4, $a$ ) and cone side (Fig. $4, b$ ), respectively. In the system composed of $60 \alpha$-CD molecules, about $9 \%, 71 \%$ and $20 \%$ of population adopted the configuration of the primary rim (Fig. 4, $a$ ), cone side (Fig. 4, $b$ ) and secondary rim (Fig. 4,c), respectively. Thus, our MD simulations suggest that the most preferred configuration of the adsorbed molecules corresponds to the structure, in which $\alpha$-CD is bound by its cone side. Moreover, our MD simulations suggested that, upon the increase in concentration of $\alpha-C D$, the self-aggregation and steric repulsion among adsorbed $\alpha-C D$ molecules affect the binding preference of $\alpha-C D$ on the curved surface of the gold nanoparticle. Figure 5 shows two representative examples of the adsorbed configuration of the $\alpha$-CD molecule on the gold nanoparticle. 


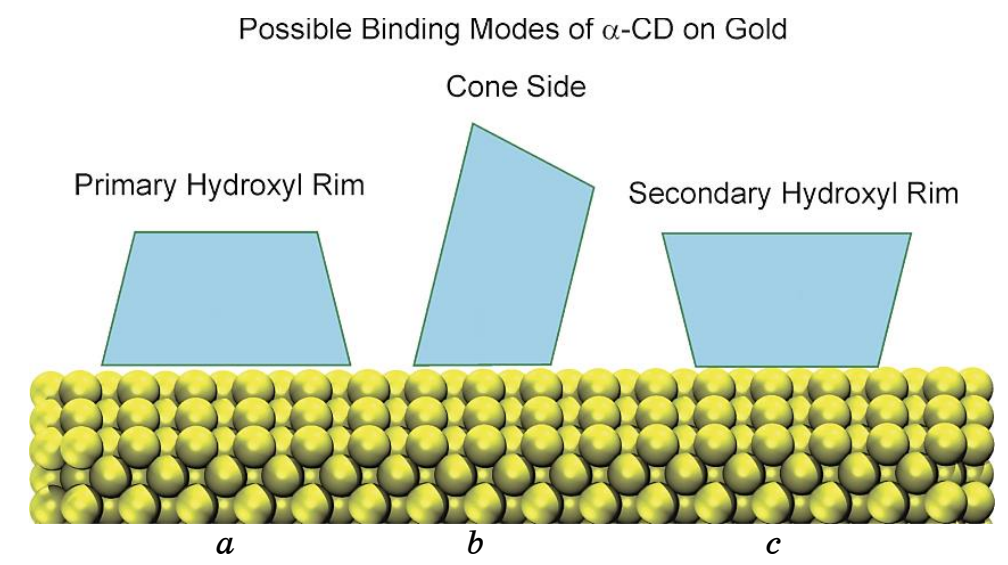

Fig. 4. Schematic view of the three possible configurations of $\alpha$-CD molecules onto the gold surface, in which $\alpha-C D$ is adsorbed by: $(a)$ the wider primary rim pointed downward, $(b)$ the cone side, (c) the narrower secondary rim pointed upward, respectively.

\section{CONCLUSIONS}

The excellent biocompatibility of cyclodextrins (CDs) and their derivatives make them especially attractive as capping agents for synthesis of gold nanoparticles (AuNPs) with adjustable sizes and shapes. However, the atomic-scale structural details and the mechanism for the stabilization of AuNPs by CDs have not been well understood and further studies in this direction are still required. To get better understanding of binding of $\alpha$-cyclodextrin $(\alpha-C D)$ onto the surface of a gold nanoparticle we used molecular dynamics (MD) simulations. Starting from randomly distributed $\alpha$-CD molecules, their adsorption dynamics onto the nanoparticle surface was found to occur at the nanosecond time-scale. Our MD simulations revealed that $\alpha$-CD molecules preferred to adsorb onto the gold nanoparticle surface through multiple non-covalent interactions, among which non-covalent bonding of the aliphatic carbon moieties play a key role. The structural analysis suggest that the most preferred binding mode of the $\alpha$-CD molecules to the gold surface corresponds to the configuration in which the $\alpha$-CD molecule is adsorbed to the surface by its cone side. In addition, self-aggregation and steric repulsion among adsorbed $\alpha-C D$ molecules can affect the binding preference of $\alpha$-CD on the surface of the gold nanoparticle, so that some minor populations of other $\alpha$-CD configurations bound by its primary and secondary rims were also observed. The detailed understanding of intermolecular interactions of CDs adsorbed on AuNPs through MD simulations provides insight for gold nanoparticle sta- 
bilization and these findings will be relevant for broad applications on nanoparticle-based interfacial studies and applications.

\section{REFERENCES}

1. S. S. Lucky, K. C. Soo, and Y. Zhang, Chem. Rev., 115: 1990 (2015); https://doi.org/10.1021/cr5004198.

2. A. R. Tao, S. Habas, and P. Yang, Small, 4: 310 (2008); https://doi.org/10.1002/smll.200701295.

3. C. J. Murphy, A. M. Gole, J. W. Stone, P. N. Sisco, A. M. Alkilany, E. C. Goldsmith, and S. C. Baxter, Acc. Chem. Res., 41: 1721 (2008); https://doi.org/10.1021/ar800035u.

4. Y. Xia, K. D. Gilroy, H.-C. Peng, and X. Xia, Angew. Chem. Int. Ed., 56: 60 (2017); https://doi.org/10.1002/anie.201604731.

5. J.-P. Sylvestre, A. V. Kabashin, E. Sacher, M. Meunier, and J. H. T. Luong, J. Am. Chem. Soc., 126: 7176 (2004); https://doi.org/10.1021/ja048678s.

6. T. Huang, F. Meng, and L. Qi, J. Phys. Chem. C, 113: 13636 (2009); https://doi.org/10.1021/jp903405y.

7. J. Suбrez-Cerda, G. A. Nucez, H. Espinoza-Gymez, and L. Z. Flores-Lypez, Mater. Sci. Eng. C, 43: 21 (2014); https://doi.org/10.1016/j.msec.2014.07.006.

8. Y. Liu, K. B. Male, P. Bouvrette, and J. H. T. Luong, Chem. Mater., 15: 4172 (2003); https://doi.org/10.1021/cm0342041.

9. A. Kyrychenko, G. V. Karpushina, S. I. Bogatyrenko, A. P. Kryshtal, and A. O. Doroshenko, Comput. Theor. Chem., 977: 34 (2011); https://doi.org/10.1016/j.comptc.2011.09.003.

10. A. Kyrychenko, G. V. Karpushina, D. Svechkarev, D. Kolodezny, S. I. Bogatyrenko, A. P. Kryshtal, and A. O. Doroshenko, J. Phys. Chem. C, 116: 21059 (2012); https://doi.org/10.1021/jp3060813.

11. A. Kyrychenko, Phys. Chem. Chem. Phys., 17: 12648 (2015); https://doi.org/10.1039/C5CP01136A.

12. A. Kyrychenko, O. M. Korsun, I. I. Gubin, S. M. Kovalenko, and O. N. Kalugin, J. Phys. Chem. C, 119: 7888 (2015); https://doi.org/10.1021/jp510369a.

13. M. M. Blazhynska, A. V. Kyrychenko, and O. N. Kalugin, Kharkov University Bulletin Chemical Series, 29 (52): 23 (2017); https://doi.org/10.26565/2220-637X-2017-29-02.

14. A. Kyrychenko, D. A. Pasko, and O. N. Kalugin, Phys. Chem. Chem. Phys., 19: 8742 (2017); https://doi.org/10.1039/C6CP05562A.

15. M. M. Blazhynska, A. Kyrychenko, and O. N. Kalugin, Mol. Simul., 44: 981 (2018); https://doi.org/10.1080/08927022.2018.1469751.

16. A. Kyrychenko, M. M. Blazhynska, M. V. Slavgorodska, and O. N. Kalugin, J. Mol. Liq., 276: 243 (2019); https://doi.org/https://doi.org/10.1016/j.molliq.2018.11.130.

17. R. G. Capelo, L. Leppert, and R. Q. Albuquerque, J. Phys. Chem. C, 118: 21647 (2014); https://doi.org/10.1021/jp5058258.

18. H. Heinz, R. A. Vaia, B. L. Farmer, and R. R. Naik, J. Phys. Chem. C, 112: 17281 (2008); https://doi.org/10.1021/jp801931d. 
19. A. Ryzhakov, T. Do Thi, J. Stappaerts, L. Bertoletti, K. Kimpe, A. R. Sá Couto, P. Saokham, G. Van den Mooter, P. Augustijns, G. W. Somsen, S. Kurkov, S. Inghelbrecht, A. Arien, M. I. Jimidar, K. Schrijnemakers, and T. Loftsson, J.Pharm. Sci., 105: 2556 (2016); https://doi.org/10.1016/j.xphs.2016.01.019.

20. C. Cezard, X. Trivelli, F. Aubry, F. Djedaini-Pilard, and F.-Y. Dupradeau, Phys. Chem. Chem. Phys., 13: 15103 (2011); https://doi.org/10.1039/C1CP20854C.

21. E. Mixcoha, J. Campos-Terán, and Á. Piceiro, J. Phys. Chem. B, 118: 6999 (2014); https://doi.org/10.1021/jp412533b.

22. H. Zhang, T. Tan, C. Hetényi, Y. Lv, and D. van der Spoel, J. Phys. Chem. C, 118: 7163 (2014); https://doi.org/10.1021/jp412041d.

23. H. Zhang, T. Tan, W. Feng, and D. van der Spoel, J. Phys. Chem. B, 116: 12684 (2012); https://doi.org/10.1021/jp308416p.

24. H. Zhang, T. Tan, and D. van der Spoel, J. Chem. Theory Comput., 11: 5103 (2015); https://doi.org/10.1021/acs.jctc.5b00620.

25. W. Khuntawee, P. Wolschann, T. Rungrotmongkol, J. Wong-Ekkabut, and S. Hannongbua, J. Chem. Inf. Model., 55: 1894 (2015); https://doi.org/10.1021/acs.jcim.5b00152.

26. P. Brocos, N. Díaz-Vergara, X. Banquy, S. Pérez-Casas, M. Costas, and Á. Piceiro, J. Phys. Chem. B, 114: 12455 (2010); https://doi.org/10.1021/jp103223u.

27. J. Gebhardt and N. Hansen, Fluid Phase Equilibria, 422: 1 (2016); https://doi.org/10.1016/j.fluid.2016.02.001.

28. C. A. Lypez, A. H. de Vries, and S. J. Marrink, Sci. Rep., 3: 02071/1 (2013); https://doi.org/10.1038/srep02071.

29. M. I. Sancho, S. Andujar, R. D. Porasso, R. D. Enriz, J. Phys. Chem. B, 120: 3000 (2016); https://doi.org/10.1021/acs.jpcb.5b11317.

30. M. Jana and S. Bandyopadhyay, Langmuir, 25: 13084 (2009); https://doi.org/10.1021/la902003y.

31. M. Jana and S. Bandyopadhyay, Langmuir, 26: 14097 (2010); https://doi.org/10.1021/la101927g.

32. M. Jana and S. Bandyopadhyay, J. Phys. Chem. B, 115: 6347 (2011); https://doi.org/10.1021/jp2013946.

33. J. Chief Elk and I. Benjamin, Langmuir, 31: 5086 (2015); https://doi.org/10.1021/acs.langmuir.5b01025.

34. H. Zhang, C. Ge, D. van der Spoel, W. Feng, and T. Tan, J. Phys. Chem. B, 116: 3880 (2012); https://doi.org/10.1021/jp300674d.

35. J. He, C. Chipot, X. Shao, and W. Cai, J. Phys. Chem. C, 118: 24173 (2014); https://doi.org/10.1021/jp507325j.

36. Y. Liu, C. Chipot, X. Shao, and W. Cai, RSC Adv., 5: 57309 (2015); https://doi.org/10.1039/C5RA05642J.

37. K. D. Tidemand, C. Schцnbeck, R. Holm, P. Westh, and G. H. Peters, J. Phys. Chem. B, 118: 10889 (2014); https://doi.org/10.1021/jp506716d.

38. K. J. Naidoo, M. R. Gamieldien, J. Y.-J. Chen, G. Widmalm, and A. Maliniak, J. Phys. Chem. B, 112: 15151 (2008); https://doi.org/10.1021/jp805174y.

39. J. Rodriguez, D. Hernбn Rico, L. Domenianni, and D. Laria, J. Phys. Chem. $B$, 112: 7522 (2008); https://doi.org/10.1021/jp711609q.

40. C. Schönbeck, P. Westh, and R. Holm, J. Phys. Chem. B, 118: 10120 (2014); 
https://doi.org/10.1021/jp506001j.

41. W. Cai, T. Sun, X. Shao, and C. Chipot, Phys. Chem. Chem. Phys., 10: 3236 (2008); https://doi.org/10.1039/B717509D.

42. K. J. Naidoo, J. Y.-J. Chen, J. L. M. Jansson, G. Widmalm, and A. Maliniak, J. Phys. Chem. B, 108: 4236 (2004); https://doi.org/10.1021/jp037704q.

43. W.-S. Li, S.-C. Wang, T.-S. Hwang, and I. Chao, J. Phys. Chem. B, 116: 3477 (2012); https://doi.org/10.1021/jp207985q.

44. R. V. Pinjari, K. A. Joshi, and S. P. Gejji, J. Phys. Chem. A, 110: 13073 (2006); https://doi.org/10.1021/jp065169z.

45. W. Snor, E. Liedl, P. Weiss-Greiler, A. Karpfen, H. Viernstein, and P. Wolschann, Chem. Phys. Lett., 441: 159 (2007); https://doi.org/10.1016/j.cplett.2007.05.007.

46. C. P. A. Anconi, C. S. Nascimento, J. Fedoce-Lopes, H. F. Dos Santos, and W. B. De Almeida, J. Phys. Chem. A, 111: 12127 (2007); https://doi.org/10.1021/jp0762424.

47. V. Jiménez and J. B. Alderete, J. Phys. Chem. A, 112: 678 (2008); https://doi.org/10.1021/jp073011o.

48. A. Stachowicz, A. Styrcz, J. Korchowiec, A. Modaressi, and M. Rogalski, Theor. Chem.Acc., 130: 939 (2011); https://doi.org/10.1007/s00214-011-1014-9.

49. T. Heine, H. F. Dos Santos, S. Patchkovskii, and H. A. Duarte, J. Phys. Chem. A, 111: 5648 (2007); https://doi.org/10.1021/jp068988s.

50. O. Guvench, S. S. Mallajosyula, E. P. Raman, E. Hatcher, K. Vanommeslaeghe, T. J. Foster, F. W. Jamison, and A. D. MacKerell, J. Chem. Theory Comput., 7: 3162 (2011); https://doi.org/10.1021/ct200328p.

51. H. Heinz, T.-J. Lin, R. Kishore Mishra, and F. S. Emami, Langmuir, 29: 1754 (2013); https://doi.org/10.1021/la3038846.

52. H. Heinz and H. Ramezani-Dakhel, Chem. Soc. Rev., 45: 412 (2016); https://doi.org/10.1039/C5CS00890E.

53. J. Hermans, H. J. C. Berendsen, W. F. Van Gunsteren, and J. P. M. Postma, Biopolymers, 23: 1513 (1984); https://doi.org/10.1002/bip.360230807.

54. G. Bussi, D. Donadio, and M. Parrinello, J. Chem. Phys., 126: 014101 (2007); https://doi.org/10.1063/1.2408420.

55. T. Darden, D. York, and L. Pedersen, J. Chem. Phys., 98: 10089 (1993); https://doi.org/10.1063/1.464397.

56. B. Hess, H. Bekker, H. J. C. Berendsen, and J. G. E. M. Fraaije, J. Comput. Chem., 18: 1463 (1997); https://doi.org/10.1002/(SICI)1096987X(199709)18:12<1463::AID-JCC4>3.0.CO;2-H.

57. B. Hess, J. Chem. Theory Comput., 4: 116 (2008); https://doi.org/10.1021/ct700200b.

58. D. Van Der Spoel, E. Lindahl, B. Hess, G. Groenhof, A. E. Mark, and H. J. C. Berendsen, J. Comput. Chem., 26: 1701 (2005); https://doi.org/10.1002/jcc.20291.

59. W. Humphrey, A. Dalke, and K. Schulten, J. Mol. Graphics, 14: 33 (1996); https://doi.org/10.1016/0263-7855(96)00018-5.

60. C. H. B. Ng, J. Yang, and W. Y. Fan, J. Phys. Chem. C, 112: 4141 (2008); https://doi.org/10.1021/jp710553c. 